\title{
Diversity, Nest Preferences, and Forage Plants of Stingless Bees (Hymenoptera: Apidae: Meliponini) from West Halmahera, North Moluccas, Indonesia
}

\author{
Salatnaya $\mathrm{H}^{1^{*}}$, Fuah $\mathrm{AM}^{2}$, Engel $\mathrm{MS}^{3,4}$, Sumantri $\mathrm{C}^{2}$, Widiatmaka ${ }^{5}$, Kahono $\mathrm{S}^{6}$

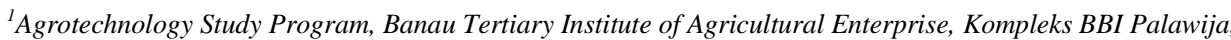 \\ Jl. Ir. Soekarno, Acango, 97752, West Halmahera, Indonesia \\ ${ }^{2}$ Department of Animal Productions and Technology, Bogor Agricultural University, Jl. Agatis, Babakan, Bogor, West Java, 16680, Indonesia \\ ${ }^{3}$ Division of Entomology, Natural History Museum, and Department of Ecology and Evolutionary Biology \\ 1501 Crestline Drive-Suite 140, University of Kansas, Lawrence \\ ${ }^{4}$ Division of Invertebrate Zoology, American Museum of Natural History, Central Park West at $79^{\text {th }}$ Street, New York, New York \\ ${ }^{5}$ Departments of Soil Science and Land Resources, Bogor Agricultural University, Jl. Ulin, Babakan, Bogor, West Java, 16680, Indonesia \\ ${ }^{6}$ Research Center for Biology, The National Research and Innovation Agency, Jalan Raya Jakarta-Bogor Km.46 Cibinong Science Center, BRIN \\ *E-mail: h.salatnaya@gmail.com
}

(received 03-09-2021; revised 28-10-2021; accepted 28-10-2021)

\begin{abstract}
ABSTRAK
Salatnaya H, Fuah AN, Engel MS, Sumantri C, Widiatmaka, Kahono S. 2021. Keragaman, preferensi bersarang, dan tanaman pakan lebah propolis (Hymenoptera: Apidae: Meliponini) dari Halmahera Barat, Maluku Utara Indonesia. JITV 26(4):167-178. DOI: http://dx.doi.org/10.14334/jitv.v26i4.2896.

Survei keragaman lebah propolis, preferensi bersarang, dan tanaman sumber pakannya dilakukan di Kabupaten Halmahera Barat pada 134 lokasi. Penelitian ini bertujuan untuk mengetahui keragaman spesies, pemilihan tempat bersarang dan habitatnya, dan jenis tanaman pakan dominan. Ditemukan tiga jenis lebah propolis, dan spesies yang paling banyak ditemukan adalah Tetragonula clypearis (Friese), diikuti oleh T. sapiens (Cockerell), dan T. biroi (Friese). Berdasarkan karakter morfologi setiap spesies yang ditemukan, dibuat kunci identifikasi spesies. Koloni lebah paling banyak ditemukan pada bagian bangunan (80.39\%), diikuti pada wilayah perkebunan (13.73\%), dan hutan rakyat (5.88\%). Sebagian besar koloni bersarang di rongga batu, bagian rumah, kotak kayu, rongga pohon, batang kayu kering, akar pohon, ruas bambu, dan rongga besi. Jenis tanaman sumber pakan terdiri dari tanaman kehutanan, tanaman perkebunan, tanaman buah-buahan, sayuran, tanaman hias, dan tanaman liar dan semak. Ketiga spesies yang ditemukan merupakan catatan baru di Halmahera Barat. Lebah hidup dalam tempat-tempat berongga yang beragam yang aman bagi koloninya. Lebah memanfaatkan beragam tanaman berbunga dan mengeluarkan resin yang berada di sekitar lokasi sarang.
\end{abstract}

Kata Kunci: Keragaman, Tanaman pakan, Preferensi bersarang, Tetragonula spp., Halmahera Barat

\begin{abstract}
Salatnaya H, Fuah AN, Engel MS, Sumantri C, Widiatmaka, Kahono S. 2021. Diversity, nest preference, and forage plants of stingless bee (Hymenoptera: Apidae: Meliponini) from West Halmahera, North Moluccas, Indonesia. JITV 26(4):167-178. DOI: http://dx.doi.org/10.14334/jitv.v26i4.2896.

Survey of stingless bee diversity, nesting preferences, and forage plants was conducted in West Halmahera across 134 collection sites. This research was aimed to determine species diversity, nesting preference and habitat, and dominant forage plants. There were three species found, the most common species being Tetragonula clypearis (Friese), followed by T. sapiens (Cockerell), and last $T$. biroi (Friese). Based on the morphology characters of each species, the key identification was provided. The most colonies were found in public houses $(80.39 \%)$, followed by plantations (13.73\%), and the community forest (5.88\%), respectively. Most colonies nested in stone cavities, parts of the houses, wooden materials, tree trunks, logs, tree roots, bamboo, and sometimes iron cavities. The forage plants consist of forage plantation, crops, fruits, vegetables, ornamental flowers, wild plants and shrubs. The three species found were new record in West Halmahera. Bees lived in various hollow places that were safe for their colony. Bees made use of a variety of flowering plants and secrete resins around the nest site.
\end{abstract}

Key Words: Diversity, Forage plants, Nesting preference, Tetragonula spp., West Halmahera

\section{INTRODUCTION}

Stingless bees (Meliponini) are social bees living naturally in tropical and sub-tropical (Michener 2007; Engel \& Rasmussen 2021). The group is most diverse in the Neotropical Region, but within the Eastern Hemisphere the tribe is most species-rich across Indonesia, with about 46 species (Kahono et al. 2018). In natural settings species build their nests within tree trunks, broken walls, and under house roofs (Kumar et 
al. 2012). The workers collect nectar and pollen from diverse floral sources and concomitantly pollinate these plants and are therefore critical pollinators of natural and agricultural ecosystems (Widhiono et al. 2016). Like honey bees (Apis L.), stingless bees produce honey but also produce propolis (Halcroft et al. 2013). Owing to their smaller body sizes and often smaller colony sizes, the volume of honey produced is of a lesser volume than that of Apis, stingless bee honey is nonetheless of considerable benefit for human health and is often of higher monetary value (Kumar et al. 2012; Chuttong et al. 2015). There is, however, a considerable geographic bias in our understanding of stingless bee diversity, nesting biology, floral associations, and management practices, with most information deriving from a subset of species from the western islands (Engel et al. 2018). The distribution and biology of species across the eastern islands, particularly those of the Moluccas, eastern Lesser Sunda islands, West Papua, and Papua, remain poorly documented (Engel 2019).

Herein we explored the diversity and biology of stingless bees in West Halmahera District, a district of the North Moluccas where meliponines are known to occur natively and which the indigenous people refer to as Caka ngau, Dadaaka or Ofu Gula. Within the area there is considerable availability and access to an array of floral sources (crop fields, horticultural plants, plantation, as well as the native forest), and these produce nectar, pollen, as well as resins used by the bees. Sampling of bees across the Moluccas has been exceptionally poor and remains one of the highest priority regions for study, and where there are exceedingly few records for stingless bees (e.g., Rasmussen 2008; Engel 2019). Tetragonula clypearis (Friese) was recorded from Ambon, but also is well known from New Guinea and Australia (Dollin et al. 1997; Rasmussen 2008); and sundry records exist for $T$. sapiens (Cockerell) and T. laeviceps (Smith) (Kahono et al. 2018). From the North Moluccas documentation of stingless bees remains untouched, and native bee pollinators (not only stingless bees) have generally been overlooked despite their critical value for sustainable agricultural development, the cultivation of natural environments, and the management of hives for honey production and economic growth. Research is needed to determine the diversity of all bee species, understand native bee nesting requirements, and their floral relation to local food crops in West Halmahera District. The focus of the present project was to identify the species of stingless bees occurring in the area, explore the nesting preferences of these species, and to provide notes on their observed visitation of regional floral resources. Future research will expand into the other lineages of bees, notably the solitary bee fauna, of the region.

\section{MATERIALS AND METHODS}

\section{Location}

This research was conducted in West Halmahera District: Jailolo Sub-District, South Jailolo Sub-District, Sahu Sub-District, East Sahu Sub-District, Ibu SubDistrict, South Ibu Sub-District, and Tabaru SubDistrict.

\section{Observation of stingless bee nesting sites and feed plants}

Sampling locations was determined based on a survey of meliponine nest availability, and these locations were marked with a Global Position System (GPS). The bees were collected after nests were found, followed by recording of the coordinates, the nests' general site, and the kinds of vegetation around each location (Figure 1). The nest entrance of each colony was directly observed and photographed. Similarly, the types of forage plants and resin plants were observed directly and photographed, to which we noted the local names, and identified the floral species using Backer \& Brink $(1963 ; 1965 ; 1968)$, which were then confirmed by the curator of the herbarium

\section{Collection, preservation, and identification of stingless bee specimens}

Bees were collected by net from nest entrances (when found), and euthanized in killing jars with cotton dipped in ethyl acetate. Specimens were kept in paper (10 individuals per colony), labeled with the geocoordinates from where they were sampled, along with the date and time of sampling. Specimens are vouchered in the Entomology Laboratory, Animal Science Division, Centre of Biological Research, Indonesian Institute of Sciences in Bogor, Indonesia.

Specimens were examined using an OptilabTM Leica Wild M3B and Dino Lite AM-423x microscopes (in the Indonesian Institute of Sciences), and with an Olympus SZX12 stereomicroscope (in the University of Kansas Natural History Museum, Lawrence, Kansas, USA). Identifications were based on comparisons and measurements against reference material identified by S.F. Sakagami and other researchers in Bogoriense Zoologicum Museum, Bogor, Indonesia and in the University of Kansas Natural History Museum, Lawrence, Kansas, USA. Given that many species of stingless bees are exceedingly similar, even cryptically so, and sometimes differentiated only by minor metrics or nest architecture, particularly among species of the genus Tetragonula, measurements for populations observation also provided. Characters measured were: Body Length (BL), Compound Eye Length (EL), 
Compound Eye Width (EW), Genal Area Width (GAW), Compound Eye Range [interocular distance] (ER), Head Width (HW), Antenna Range [intertorular distance] (AR), Labrum Width (LW), Forewing $\mathrm{M}-\mathrm{Cu}$ Length (M-Cu), Metatibia Length (TL), Wing Tegula (WT), diameter of second Flagellomere (FL), Malar Space (MS).

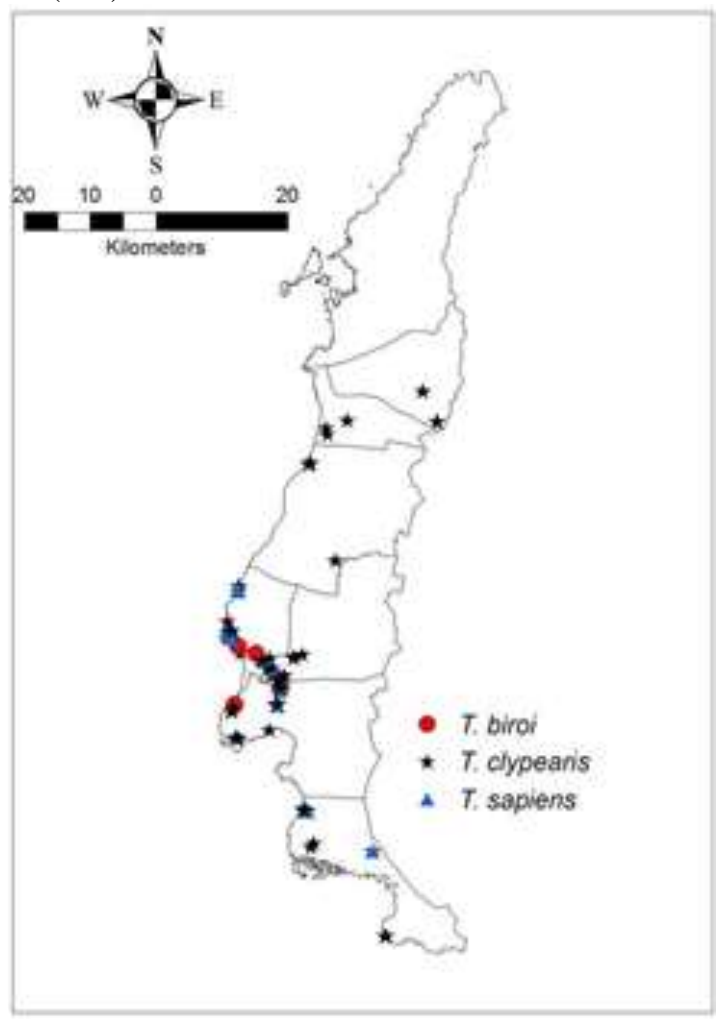

Figure 1. Collecting localities for stingless bees and floral hosts in West Halmahera District

\section{RESULTS AND DISCUSSION}

\section{Species diversity and characters in West Halmahera}

Across Halmahera District 134 colonies distributed were found, as follows: 46 colonies in Jailolo SubDistrict, 31 in Sahu Sub-District, 19 in East Sahu SubDistrict, nine in South Ibu Sub-District, three in Ibu Sub-District, four in Tabaru Sub-District, and 22 in South Jailolo Sub-District. These colonies encompassed three species that were identified as Tetragonula clypearis, T. sapiens, and T. biroi (Friese). The species were distributed as follows: all three species each in Jailolo and Sahu Sub-District; two species each in South Jailolo, Sahu and East Sahu Sub-District (T. clypearis and T. sapiens); and one species each in Ibu, South Ibu, and Tabaru Sub-Districts (all T. clypearis). Tetragonula clypearis was the most commonly encountered species in West Halmahera District, with as many as 109 colonies located $(81.34 \%)$, followed by
T. sapiens with 21 colonies (15.67\%), and four colonies of $T$. biroi $(2.99 \%)$.

Tetragonula is the genus of stingless bees with the widest range across the Indo-Pacific, and includes species of a small size, typically with five hamuli on the hind wing, with forewing vein $M$ straight and ending bluntly, and with the mesoscutellum projecting posteriorly (Rasmussen et al. 2017; Engel et al. 2018). The genus has been reported from Continental Asia and Sri Lanka (Sakagami 1978), Southeast Asia (Sakagami \& Inoue 1985; Engel et al. 2017), the Philippines (Schwarz 1939; Starr \& Sakagami 1987), Malaysia (Schwarz 1939; Salim et al. 2012; Kelly et al. 2014), Australia (Dollin et al. 1997; Halcroft et al. 2013), Thailand (Boontop et al. 2008; Engel et al. 2017), and India (Rasmussen 2013; Rathor et al. 2013). In Indonesia, Tetragonula has been reported from Sulawesi (Schwarz 1939), East Kalimantan (Syafrizal et al. 2012; 2014), West Sumatera (D.. Putra et al. 2016), Bali (N.S. Putra et al. 2016), Java, Borneo, Ambon, Moluccas, and Papua (Schwarz 1939; Kahono et al. 2018). Extensive surveys of the smaller archipelagos are needed to further explore the distribution of the species and look for endemic populations or additional species.

Three species - T. clypearis, T. sapiens, and T. biroi - were collected from Halmahera with $T$. clypearis the most commonly encountered, followed by $T$ sapiens and $T$. biroi. Previous studies showed that broadly across the Moluccas there are additional species of stingless bees, with Platytrigona keyensis on Kei Island, T. clypearis on Ambon (Rasmussen 2008), and $T$. laeviceps (Smith) and T. sapiens (Cockerell) (Dollin et al. 1997; Rasmussen 2008; Kahono et al. 2018), while $T$. biroi was previously only recorded from Sulawesi and Irian Jaya (Suriawanto et al. 2017; Kahono et al. 2018). The three species recently found in West Halmahera were new records from the Northern Moluccas, especially Halmahera Island.

Morphological characteristics of workers in each species are distinct (Figs. 2-4). Tetragonula clypearis has a small size with a body length of $3.16 \pm 0.19 \mathrm{~mm}$, while $T$. sapiens and $T$. biroi are larger and have body lengths of $3.91 \pm 0.06 \mathrm{~mm}$ and $4.74 \pm 0.21 \mathrm{~mm}$, respectively. Measurement of the characters is provided in Table 1. Tetragonula clypearis has variation in body color, and can be pale like $T$. minangkabau (Sakagami and Inoue), and pale with dark (nearly black) stripes, with areas of yellow and black (Figure 2). The mesosoma is black and setae are prevalent, the metatibia is dark brown, and there are six longitudinal setal bands on the mesoscutum (Figure 5C), like that of $T$. fuscobalteata (Cameron). Tetragonula sapiens has a black mesosoma and the mesoscutum is setose (Figure 3), while the pleura have white setae but these are not evenly distributed (Figure 
5G). The metasoma is dark brown, sometimes with a slight golden hue posteriorly (Figure 3). The mesosoma of $T$. biroi is black with diffuse white setae, the metasoma is blackish brown (Figure 4), and the setae of the pleura are uniform (Figure 5E).

Identification of Tetragonula is generally a difficult matter as the species often differ in minor details and several closely related species can be easily confused. Added to this difficulty is the reality that several species have notable variation in size and color, potentially leading to misidentifications when attempting to rely heavily on mere metrics and color patterns (in fact, it is believed that color is a notoriously misleading feature in many species groups of Tetragonula and so should be used with caution). Tetragonula clypearis in Halmahera was found to have a body length not differing from that reported earlier, 3.2-3.7 $\mathrm{mm}$ (Dollin et al. 1997). Nonetheless, the head width was smaller than that found by Dollin et al. (1997), at $1.57 \pm 0.03 \mathrm{~mm}$, but the metatibia length effectively equivalent, at $1.46 \pm$ $0.03 \mathrm{~mm}$ (Dollin et al. 1997). Eye length differed from populations of $T$. clypearis studied by Dollin et al. (1997), with the Halmahera population measuring at $1.04 \pm 0.02 \mathrm{~mm}$. The forewing $\mathrm{M}-\mathrm{Cu}$ also differed at $0.97 \pm 0.04 \mathrm{~mm}$. The overall wing length, including the tegula, was found to be identical to that recorded by Dollin et al. (1997), 3.4 - $3.7 \mathrm{~mm}$. Overall, the metasoma colour was similar to that of $T$. fuscobalteata, blackish brown, but also at times exhibited a more pale colour like $T$. minangkabau with the metatibia darker (Schwarz 1939; Sakagami \& Inoue 1985).

Tetragonula sapiens had been reported previously from the Moluccas. Tetragonula sapiens had a similar colour, size, and structure with T. laeviceps (Schwarz 1939; Dollin et al. 1997). The size of our T. sapiens differed slightly from that of the populations studied by Dollin et al. (1997), having a length of $3.6-4.2 \mathrm{~mm}$, but colouration was the same (Schwarz 1939). Eye length also differed at $1.28 \pm 0.01 \mathrm{~mm}$, but the head width was equivalent to that found by Dollin et al. (1997), with the Halmahera population measuring $1.85 \pm 0.03 \mathrm{~mm}$. The forewing $\mathrm{M}-\mathrm{Cu}$ was larger at $0.97 \pm 0.04 \mathrm{~mm}$, while the metatibia length was shorter at $1.80 \pm 0.05 \mathrm{~mm}$ (Dollin et al. 1997). The Halmahera population of $\mathrm{T}$. biroi was slightly larger than that of Suriawanto et al. (2017) found on Sulawesi, with ours being 4.00-4.17 mm. Other measurements could not be compared as these authors did not record the same metrics, but colour of the mesosoma on Sulawesi was brownish (Suriawanto et al. 2017). It remains to be determined whether these minor variations in proportions and colouration could be correlated with local microhabitat differences such as elevation, surrounding vegetation, humidity fluctuations, food sources, \&c. Generally, this remains an underexplored area in meliponine biology, as there is little information on the degree to which regional floral resources, elevations, and habitats have on the development of ecological variations among populations of a stingless bee species, or between species, and how these might ultimately relate to speciation over geological time.

The following dichotomous key provided as an aid to the identification of the species in the region. It is noted with caution that this key is good only for the fauna of Halmahera and should not be used for other islands without confirming the identification of species against reference material (e.g., the first couplet generally distinguishes species of the carbonaria species group from others, and while these are sufficient to regionally distinguish $T$. biroi, it would not sufficiently distinguish $T$. biroi from other species of the same species group in areas where other members of the carbonaria group occur together).

Key to Species of Tetragonula from West Halmahera (based on morphological characters of the worker caste):

1. Mesepisternum sparsely setose in posterior half, contrasting the densely covered anterior half (Figure. 5F, 5G); malar space nearly obsolescent, linear (Figure 5B), length $0.2 \times$ (or much less) diameter of second flagellomere -. Mes- and metepisternum densely and uniformly covered with fine, short setae (Figure $5 \mathrm{E}$ ); malar space short but distinct (Figure 5A), length nearly $0.5 \times$ diameter of second flagellomere ........... T. biroi (Friese)

2. Mesoscutum with longitudinal bands of diffuse setae separated by narrow glabrous interspaces (Figure 5C); smaller species, wing length (including tegula) $3.4-3.8 \mathrm{~mm}$.................... $T$. clypearis (Friese)

- Mesoscutum evenly setose, without defined bands separated by glabrous interspaces (Figure 5D); larger species, wing length (including tegula) $4.1-4.7 \mathrm{~mm}$ T. sapiens (Cockerell)

\section{Nesting sites of Tetragonula in West Halmahera}

Colonies were found in public areas, plantations, and the forest. Interestingly, most colonies were found in public areas $(85.07 \%)$, followed by plantations $11.19 \%$, and the forest $(3.73 \%)$. This result seems counterintuitive, but colonies in forest settings were more difficult to locate owing to the natural defense of stingless bees to obscure their nests (Michener, 2013). 51 colonies were nesting in house foundations $(38.06 \%)$, followed by 27 colonies $(20.15 \%)$ in portions 


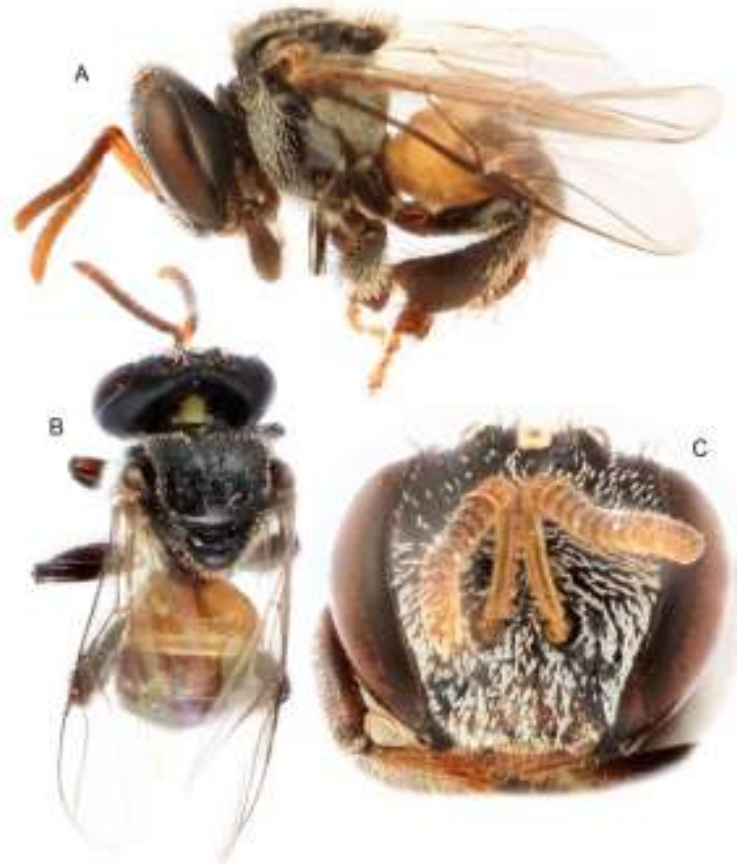

Figure 2. Tetragonula (Tetragonula) clypearis (Friese) from West Halmahera District. A. Lateral habitus. B. Dorsal habitus. C. Facial view.

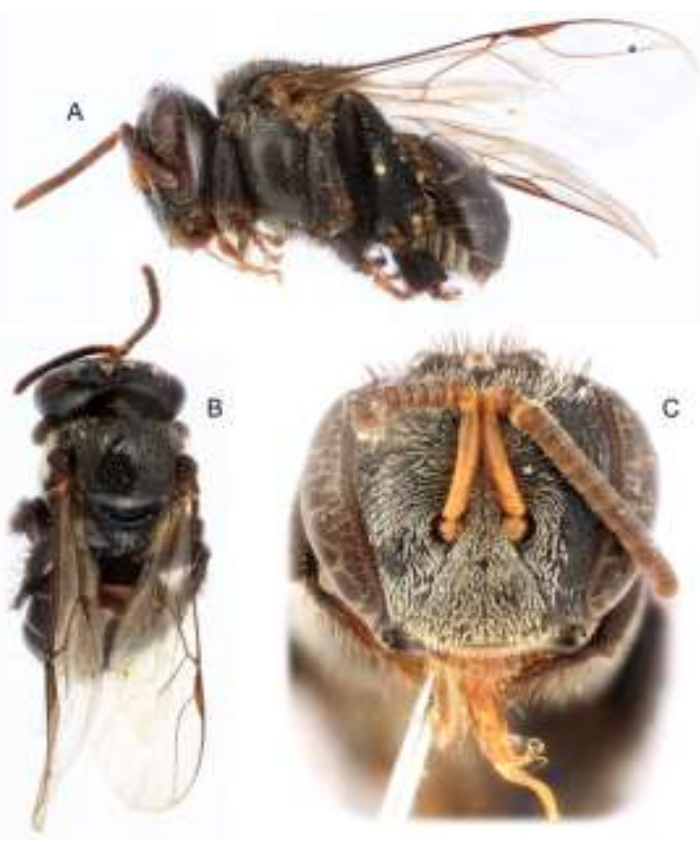

Figure 4. Tetragonula (Tetragonula) biroi (Friese) from West Halmahera District. A. Lateral habitus. B. Dorsal habitus.

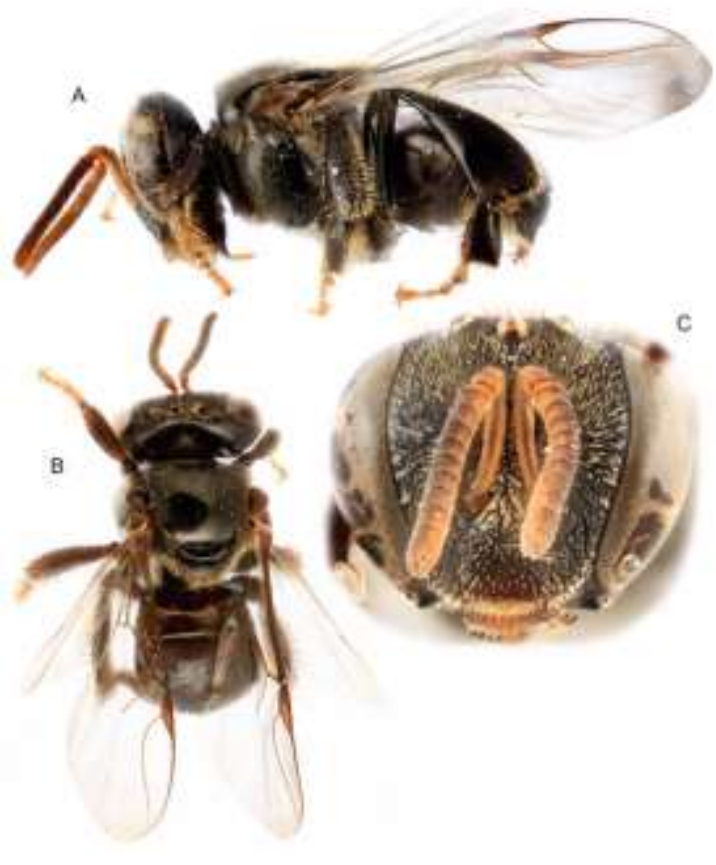

Figure 3. Tetragonula (Tetragonula) sapiens (Cockerell) from West Halmahera District. A. Lateral habitus. B. Dorsal habitus. C. Facial view.

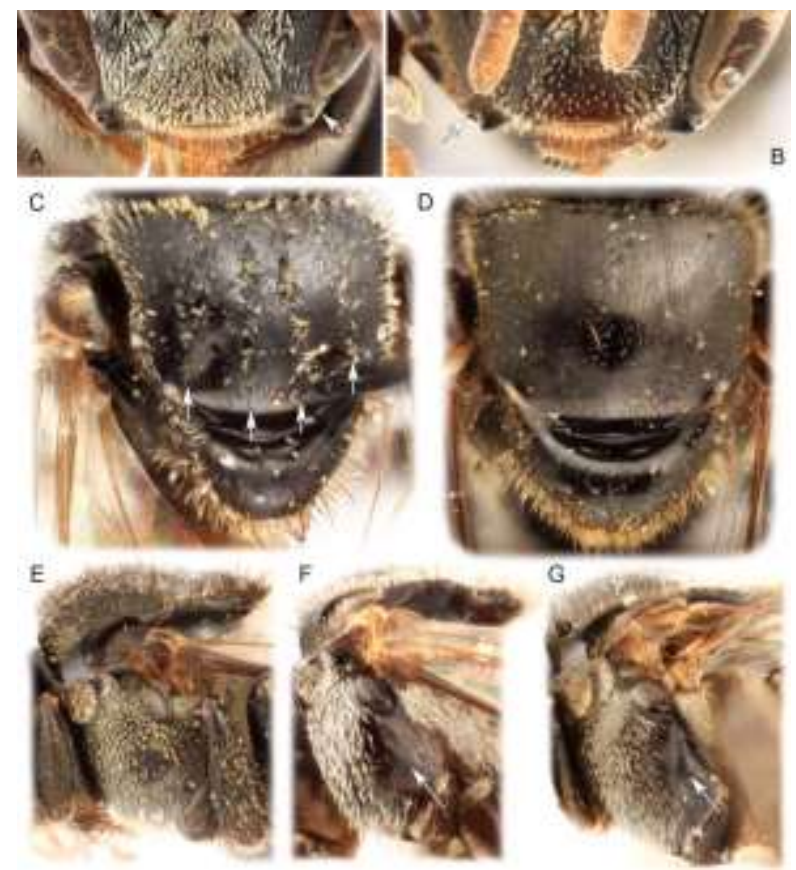

Figure 5. Distinguishing features of species of Tetragonula Moure from West Halmahera District. A. Malar space (arrow) of Tetragonula biroi (Friese). B. Malar space (arrow) of T. sapiens (Cockerell). C. 
of houses, 16 colonies $(11.94 \%)$ in stone cavities, 14 colonies $(10.45 \%)$ in tree trunks, nine colonies $(6.72 \%)$ in wooden materials, five colonies $(3.73 \%)$ in bamboo poles, three colonies $(2.24 \%)$ in furniture and electrical boxes, two colonies (1.49\%) in a log and iron cavity, and one colony $(0.75 \%)$ in exposed tree roots above the ground.

Mostly colonies of the small species were located, T. clypearis (109 colonies), with the 43 nesting sites (39.45\%) in house foundations, 27 colonies $(24.77 \%)$ on parts of houses (e.g., bamboo poles, wooden frames, wall spaces, and even a keyhole), 15 colonies $(13.75 \%)$ in stone cavities, and 24 colonies $(14.68 \%)$ in wooden nests, bamboo poles, furniture, electrical boxes, an iron cavity, tree trunk, or log. The prevalence of this species in public spaces may relate to its smaller size, permitting it to occupy cavities too small for the other species and also perhaps permitting them to go more easily unnoticed. Tetragonula sapiens had nine colonies $(42.86 \%)$ in Gufasa (Vitex coffasus) trunks, eight colonies $(38.10 \%)$ in house foundations, and one colony each $(4.76 \%)$ in the roots of coconut (Cocos nucifera), a $\log$, and exposed roots above the ground, respectively. Three colonies of $T$. biroi $(75 \%)$ were found living in tree trunks and one colony living in wooden material. These nest locations are tabulated in Table 2.

As in any social arthropod, the nest is critical for defense and establishing a stable and suitable microclimate in which to store resources and develop brood (Nayak et al. 2013). We found that stingless bees in Halmahera live in unpredictable places, similar to that found by prior researchers, and can be found in protected cavities of many sorts, such as walls, logs, live and dead tree trunks, and even sometimes in the ground (Schwarz 1939; Sommeijer 1999; Eltz et al. 2003). Nests of Tetragonula were found in Halmahera mostly in settled areas, similar to those in Sulawesi (Suriawanto et al. 2017). Nests were also found at times in cavities of termite nests, buildings, stone, bamboo, wooden walls, iron spaces, pillars, metallic sheaths, water pipes, and brick walls (Jongjitvimol \& Wattanachaiyingcharoen 2007; Nayak et al. 2013; Suriawanto et al. 2017). We also found nests in the forest, supported by the previous study in Thailand, with nests of Tetragonula in dry dipterocarp forest, upper mixed deciduous forest, lower mixed deciduous forest, and dry evergreen forest (Boontop et al. 2008; Engel et al. 2017). Protected areas were frequently selected for nests, and sometimes they built in the area with food resources nearby, but such factors did not always correlate with nesting site preferences (Nayak et al. 2013).

\section{Forage plants of Tetragonula in West Halmahera}

We found 77 species of food plants being used for either nectar and/or pollen and at times also for resins. These floral and resin sources represented nine species of forage plantations, four species of plantation crops, 23 species of fruit plantations, six species of vegetable crops, 22 species of ornamental plants, and 13 wild plants and shrubs (Table 3 ). Stingless bees require resin in order to construct nests, although bees at resinproducing plants specifically were not documented, nine species of resinous plants at collection localities were located and these are likely suitable sources for these bees. Further study is needed to see if the bees preferentially visit one or more of these resin sources, or if they generally visit any of these plants. In addition, the chemical properties of the resins need to be examined to determine their properties, such as viscosity, acidity, preservative compounds, microbiome, toxins, \&c. These factors may render certain resins more or less beneficial as nest components and could potentially relate to preferences on the part of all or some of the species, should such behaviours exist. In addition, it remains to be examined how the bees manipulate the resin and whether there are specific ethologies associated with resin collection in the Tetragonula from Halmahera. Future studies should compare the chemical properties and microbiomes of the nine resin-producing plants in the area with the chemistry of those resins found in nests of the three regional species of Tetragonula. A detailed comparison between the microbiome of the bees' intestinal tracts, those of their resins, those of their host plants, and those of their nest storages would be critical for evaluating the role of microbial communities for shaping the ecology of these bees. To date, the microbiome has not been explored in any species of Tetragonula.

Worker bees visited many flowers and cared for brood throughout the year (Engel \& Dingeman-Bakels 1980). We found various crops, ornamentals, and wild plants used by stingless bees around their nest site. Ramalho et al. (1990) found the same in their study, with their bees visiting various plants from the families Caricaceae, Euphorbiaceae, Fabaceae, Arecaceae, and Rutaceae. The generally small body size of Tetragonula allows for workers to visit myriad smaller flowers not visited by larger bees such as Apis, Callomegachile, and Amegilla. Our populations collected resins from at least Artocorpus heterophyllus Lam, Moringa oleifera, Mangifera indica, and Vinca rosea L (Roopa et al. 2017), but the association of Halmahera's populations of Tetragonula with their resin-producing plants is in need of deeper exploration. 
Table 1. Measurements of stingless bees in West Halmahera District in millimeters.

\begin{tabular}{|c|c|c|c|c|c|c|c|c|c|}
\hline \multirow{2}{*}{ Character } & \multicolumn{3}{|c|}{ Tetragonula clypearis } & \multicolumn{3}{|c|}{ Tetragonula sapiens } & \multicolumn{3}{|c|}{ Tetragonula biroi } \\
\hline & $\mathrm{N}$ & Mean & SD & $\mathrm{N}$ & Mean & SD & $\mathrm{N}$ & Mean & SD \\
\hline Body Length (BL) & 109 & 3.16 & 0.19 & 21 & 3.91 & 0.06 & 4 & 4.74 & 0.21 \\
\hline Compound Eye Length (EL) & 109 & 1.05 & 0.02 & 21 & 1.27 & 0.01 & 4 & 1.22 & 0.01 \\
\hline Compound Eye Width (EW) & 109 & 0.39 & 0.01 & 21 & 0.50 & 0.00 & 4 & 0.47 & 0.01 \\
\hline Genal Area Width (GAW) & 109 & 0.20 & 0.02 & 21 & 0.25 & 0.01 & 4 & 0.23 & 0.00 \\
\hline Forewing $\mathrm{M}-\mathrm{Cu}$ Length $(\mathrm{M}-\mathrm{Cu})$ & 109 & 0.90 & 0.02 & 21 & 1.12 & 0.01 & 4 & 1.16 & 0.02 \\
\hline Metatibia Length (TL) & 109 & 1.42 & 0.05 & 21 & 1.74 & 0.01 & 4 & 1.68 & 0.01 \\
\hline Head Width (HW) & 109 & 1.54 & 0.02 & 21 & 1.85 & 0.01 & 4 & 1.85 & 0.01 \\
\hline Antenna Range (AR) & 109 & 0.15 & 0.01 & 21 & 0.18 & 0.00 & 4 & 0.18 & 0.01 \\
\hline Labrum Width (LW) & 109 & 0.34 & 0.02 & 21 & 0.44 & 0.01 & 4 & 0.46 & 0.01 \\
\hline Compound Eye Range (ER) & 109 & 1.05 & 0.02 & 21 & 1.21 & 0.01 & 4 & 1.27 & 0.02 \\
\hline Wing Tegula (WT) & 109 & 3.25 & 0.18 & 21 & 4.13 & 0.02 & 4 & 4.41 & 0.02 \\
\hline Diameter of second Flagellomere (FL) & 109 & 0.13 & 0.00 & 21 & 0.15 & 0.00 & 4 & 0.15 & 0.00 \\
\hline Malar Space (MS) & 109 & 0.03 & 0.00 & 21 & 0.05 & 0.00 & 4 & 0.07 & 0.00 \\
\hline
\end{tabular}

Table 2. Number of nests by habitat for Tetragonula in West Halmahera District

\begin{tabular}{|c|c|c|c|c|c|}
\hline \multirow{2}{*}{ Habitat } & \multicolumn{3}{|c|}{ Species } & \multirow{2}{*}{ Total } & \multirow{2}{*}{ Percentage $(\%)$} \\
\hline & Tetragonula clypearis & Tetragonula sapiens & Tetragonula biroi & & \\
\hline Bamboo & 5 & 0 & 0 & 5 & 3.73 \\
\hline Log & 1 & 1 & 0 & 2 & 1.49 \\
\hline Part of house & 27 & 0 & 0 & 27 & 20.15 \\
\hline Stone cavity & 15 & 1 & 0 & 16 & 11.94 \\
\hline Tree trunk & 2 & 9 & 3 & 14 & 10.45 \\
\hline Root of tree & 0 & 1 & 0 & 1 & 0.75 \\
\hline Foundation & 43 & 8 & 0 & 51 & 38.06 \\
\hline Wooden Materials & 8 & 0 & 1 & 9 & 6.72 \\
\hline Furniture & 3 & 0 & 0 & 3 & 2.24 \\
\hline Electricity & 3 & 0 & 0 & 3 & 2.24 \\
\hline Iron Cavity & 2 & 0 & 0 & 2 & 1.49 \\
\hline Over the land & 0 & 1 & 0 & 1 & 0.75 \\
\hline \multicolumn{4}{|c|}{ TOTAL } & 134 & 100 \\
\hline
\end{tabular}


Table 3. Forage plants of Tetragonula in West Halmahera District

\begin{tabular}{|c|c|c|c|c|c|c|c|c|}
\hline No & Family & Species name & Traditional name & Nectar & Pollen & Resin & Native & Introduced \\
\hline \multicolumn{9}{|c|}{ Forage Plantation } \\
\hline 1 & Araucariaceae & Agathis dammara (Lamb.) L.C. Rich ${ }^{2}$ & Damar & * & * & $*$ & $*$ & \\
\hline 2 & Arecaceae & Arenga pinnata (Wurmb) Merr. ${ }^{2,3}$ & Aren & $*$ & $*$ & & $*$ & \\
\hline 3 & Casuarinaceae & Casuarina $\mathrm{L}^{2}$ & Cemara-cemaraan & & & $*$ & $*$ & \\
\hline 4 & Clusiaceae & Callophylum inophyllum L. ${ }^{1,2,3}$ & Nyamplung & & * & * & * & \\
\hline 5 & Euphorbiaceae & Manihot carthaginensis subsp. Glaziovii ${ }^{1,2}$ & Singkong Karet & & & $*$ & $*$ & \\
\hline 7 & Moraceae & Artocarpus altilis (Parkinson) Fosberg 2 & Sukun & & * & $*$ & $*$ & \\
\hline 8 & Pinaceae & Pinus $\mathrm{L}^{2}$ & Pinus & & & $*$ & $*$ & \\
\hline \multirow[t]{2}{*}{9} & Rubiaceae & Morinda citrifolia L. $^{2}$ & Mengkudu & $*$ & $*$ & & $*$ & \\
\hline & \multicolumn{8}{|c|}{ Crops } \\
\hline 1 & Arecaceae & Cocos nucifera $\mathrm{L}^{1,2}$ & Kelapa & $*$ & * & & $*$ & \\
\hline 2 & Bombaceae & Ceiba pentandra $(\mathrm{L})$ Gaertn $^{2}$ & Kapuk Randu & $*$ & * & & * & \\
\hline \multirow[t]{2}{*}{4} & Sterculiaceae & Theobroma cacao $\mathrm{L}^{2}{ }^{2}$ & Cokelat & $*$ & & & & $*$ \\
\hline & \multicolumn{8}{|c|}{ Fruits } \\
\hline 1 & Anacardiaceae & Mangifera indica L. $^{1,2,3}$ & Mangga & $*$ & $*$ & * & $*$ & \\
\hline 2 & Anacardiaceae & Spondias dulcis L. ${ }^{2}$ & Kedondong & $*$ & * & & $*$ & \\
\hline 3 & Anacardiaceae & Anacardium occidentale $\mathrm{L}^{2}$ & Jambu Monyet & & * & & $*$ & \\
\hline 4 & Annonaceae & Annona muricata $\mathrm{L}^{2}$ & Sirsak & & * & & $*$ & \\
\hline 5 & Arecaceae & Salacca zalacca (Gaertn.) Voss ${ }^{2}$ & Salak & & * & & * & \\
\hline 6 & Bombaceae & Durio zibethinus murr. ${ }^{2}$ & Durian & $*$ & * & & * & \\
\hline 7 & Cactaceae & Hylocereus undatus (Haw.) Britton \& Rose $\mathrm{s}^{2,3}$ & Buah Naga Putih & * & * & & & $*$ \\
\hline 8 & Cactaceae & Hylocereus costaricensis (F.A.C. Weber) Britton \& Rose $e^{2,3}$ & Buah Naga Merah & $*$ & * & & & $*$ \\
\hline 9 & Caricaceae & Carica papaya $\mathrm{L}^{1}$ & Pepaya & * & * & & $*$ & \\
\hline 10 & Clusiaceae & Garcinia spp. ${ }^{2}$ & Manggis & $*$ & * & $*$ & $*$ & \\
\hline 11 & Elaeocarpaceae & Muntingia calabura L. $^{2}$ & Kersen & $*$ & * & & $*$ & \\
\hline 12 & Lauraceae & Persea americana Mill $^{2}$ & Alpukat & * & * & & * & \\
\hline 13 & Meliaceae & Lansium domesticum Corr. ${ }^{2}$ & Langsat & $*$ & & & $*$ & \\
\hline 14 & Moraceae & Artocarpus heterophylla $\mathrm{Lmk}^{2,3}$ & Nangka & & $*$ & $*$ & $*$ & \\
\hline
\end{tabular}




\begin{tabular}{|c|c|c|c|c|c|c|c|c|}
\hline No & Family & Species name & Traditional name & Nectar & Pollen & Resin & Native & Introduced \\
\hline 15 & Moraceae & Artocarpus integer (Thumb.) Merr. ${ }^{2}$ & Cempedak & & & $*$ & $*$ & \\
\hline 16 & Musaceae & Musa sp. ${ }^{2}$ & Pisang & $*$ & $*$ & & $*$ & \\
\hline 17 & Myrtaceae & Syzgium aquaeum(Burm. f.) Alston ${ }^{2,3}$ & Jambu Air & $*$ & * & & $*$ & \\
\hline 18 & Myrtaceae & Psidium guajava $\mathrm{L}^{2}$ & Jambu Biji & $*$ & * & & $*$ & \\
\hline 19 & Myristicaceae & Myristica spp. $^{1,2,3}$ & Pala & $*$ & * & $*$ & $*$ & \\
\hline 20 & Oxalidaceae & Averrhoa carambola L. $^{2}$ & Belimbing & $*$ & * & & $*$ & \\
\hline 21 & Rutaceae & Citrus microcarpa Bunge $\mathrm{e}^{1,2,3}$ & Jeruk Kasturi & $*$ & $*$ & & $*$ & \\
\hline 22 & Sapindaceae & Nephelium lappaceumL. ${ }^{2,3}$ & Rambutan & $*$ & * & & $*$ & \\
\hline \multirow[t]{2}{*}{23} & Sapindaceae & Dimocarpus longan Lour. ${ }^{1,2}$ & Lengkeng & $*$ & $*$ & & & $*$ \\
\hline & \multicolumn{8}{|c|}{ Vegetables } \\
\hline 1 & Cucurbitaceae & Cucurbita moschata Duschesne ${ }^{2}$ & Labu & $*$ & $*$ & & & $*$ \\
\hline 2 & Cucurbitaceae & Sechium edule (Jacq.) Swarz ${ }^{2}$ & Labu Siam & $*$ & & & & $*$ \\
\hline 3 & Euphorbiaceae & Manihot esculenta Crantz $^{2}$ & Singkong & $*$ & $*$ & & $*$ & \\
\hline 4 & Poaceae & Zea mays $\mathrm{L}^{2}$ & Jagung & & * & & & $*$ \\
\hline 5 & Solanaceae & Capsicum frustescens $\mathrm{L}^{2}$ & Cabai rawit & $*$ & * & & $*$ & \\
\hline \multirow[t]{2}{*}{6} & Solanaceae & Solanum melongena $\mathrm{L}^{2}$ & Terong & $*$ & $*$ & & & $*$ \\
\hline & \multicolumn{8}{|c|}{ Ornamental Flowers } \\
\hline 1 & Amaranthaceae & Celosia argentea $\mathrm{L}^{1,2}$ & Boroco & & $*$ & & $*$ & \\
\hline 2 & Asteraceae & Helianthus annusL. ${ }^{1,2}$ & Bunga Matahari & $*$ & * & & & $*$ \\
\hline 3 & Asteraceae & Tagetes erecta $\mathrm{L}^{1,2}$ & Marigold & & * & & & $*$ \\
\hline 4 & Asteraceae & Zinnia elegans Jacq. ${ }^{1,2}$ & Kembang Kertas & & $*$ & & & $*$ \\
\hline 5 & Asteraceae & Cosmos sulfureus Cav. ${ }^{1,2}$ & Kenikir Sulfur & & * & & & $*$ \\
\hline 6 & Cannaceae & Canna indica L. $^{1,2}$ & Bunga Tasbe & & $*$ & & $*$ & \\
\hline 7 & Cannaceae & Canna hybrida Hort. $^{1,2}$ & Bunga Tasbe & & $*$ & & $*$ & \\
\hline 8 & Cannaceae & Canna glauca L., ${ }^{1,2}$ & Aquatic Canna & & $*$ & & $*$ & \\
\hline 9 & Euphorbiaceae & Jatropha integerrima Jacq. ${ }^{1,2}$ & Jarak batavia & $*$ & $*$ & & $*$ & \\
\hline 10 & Euphorbiaceae & Euphorbia milli Des Moul. ${ }^{1,2,3}$ & Mahkota Duri & * & * & & $*$ & \\
\hline 11 & Euphorbiaceae & Jatropha multifida L. $^{1}$ & Jarak Cina & & $*$ & & $*$ & \\
\hline 12 & $\begin{array}{l}\text { Fabaceae } \\
\text { (Caesalpinioideae) }\end{array}$ & Caesalpinia pulcherrima (L.) Sw. ${ }^{2,3}$ & Kembang Merak & $*$ & $*$ & & $*$ & \\
\hline 13 & $\begin{array}{l}\text { Fabaceae } \\
\text { (Caesalpinioideae) }\end{array}$ & Caesalpinia pulcherrima var. flava Bailey \& Rehder ${ }^{2,3}$ & $\begin{array}{l}\text { Kembang Merak } \\
\text { Kuning }\end{array}$ & $*$ & $*$ & & $*$ & \\
\hline 14 & Fabaceae & Calliandra Benth. ${ }^{1,2,3}$ & Kaliandra & $*$ & * & & & $*$ \\
\hline
\end{tabular}




\begin{tabular}{|c|c|c|c|c|c|c|c|c|}
\hline No & Family & Species name & Traditional name & Nectar & Pollen & Resin & Native & Introduced \\
\hline & (Mimosacaceae) & & & & & & & \\
\hline 15 & $\begin{array}{l}\text { Fabaceae } \\
\text { (Mimosacaceae) }\end{array}$ & Calliandra surinamensis Benth. ${ }^{1,2}$ & Kaliandra pink & & $*$ & & $*$ & \\
\hline 16 & Malvaceae & Hibiscus rosa-sinensis plenus ${ }^{1,2}$ & $\begin{array}{l}\text { Kembang Sepatu } \\
\text { Double }\end{array}$ & & * & & $*$ & \\
\hline 17 & Malvaceae & Hibiscus rosa-sinensis L. ${ }^{1,2}$ & Kembang Sepatu & & $*$ & & $*$ & \\
\hline 18 & Plantaginaceae & Angelonia angustifolia Benth. ${ }^{1,2}$ & Angeloni Ungu & & * & & * & \\
\hline 19 & Portulacaceae & Portulaca oleracea $L_{.}^{1,2,3}$ & Bunga Pukul 9 & $*$ & * & & $*$ & \\
\hline 20 & Portulacaceae & Portulaca grandiflora Hook. ${ }^{1,2}$ & $\begin{array}{l}\begin{array}{l}\text { Bunga } \\
\text { double }\end{array} \\
\text { jam }\end{array}$ & $*$ & * & & * & \\
\hline 21 & Rubiaceae & Ixora coccinea $\mathrm{L}^{1,2}$ & Bunga Asoka & & $*$ & & $*$ & \\
\hline \multirow[t]{2}{*}{22} & Turneraceae & Turnera subulata J. E. Smith. ${ }^{1,2,3}$ & Bunga Pukul 8 & $*$ & $*$ & & $*$ & \\
\hline & \multicolumn{8}{|c|}{ Wild Plants and Shrubs } \\
\hline 1 & Acanthaceae & Asystasia gangetica (L.) T. Anderson $^{2}$ & Rumput Israel & $*$ & $*$ & & * & \\
\hline 2 & Acanthaceae & Ruellia tuberosa $\mathrm{L}^{1,2}$ & Kencana ungu liar & & * & & * & \\
\hline 3 & Asteraceae & Acmella ciliate (Kunth) Cass. (Asteraceae) $)^{1,2}$ & Jotang & & * & & $*$ & \\
\hline 4 & Asteraceae & Ageratum conyzoides $\mathrm{L} .^{2}$ & Bandotan & & * & & * & \\
\hline 5 & Asteraceae & Cyanthillium cinereum (L.) H. Rob ${ }^{2}$ & Sirangak & & * & & * & \\
\hline 6 & Asteraceae & Sphagneticola trilobata (L.) Pruski ${ }^{2}$ & $\begin{array}{l}\text { Seruni Jalar atau } \\
\text { Wedelia }\end{array}$ & & * & & * & \\
\hline 7 & Capparaceae & Cleome rutidosperma $\mathrm{DC}^{2}$ & Maman Ungu & & $*$ & & $*$ & \\
\hline 8 & $\begin{array}{l}\text { Fabaceae } \\
\text { (Mimosacaceae) }\end{array}$ & Mimosa pudica $\mathrm{L}^{2}$ & Putri Malu & & $*$ & & $*$ & \\
\hline 9 & Lythraceae & Cuphea hyssopifolia Kunth $^{2}$ & $\begin{array}{l}\text { Taiwan beauty } \\
\text { bunga ungu }\end{array}$ & & * & & $*$ & \\
\hline 10 & Nyctaginaceae & Boerhavia diffusa L. ${ }^{1,2}$ & Daun Cakaran & & $*$ & & $*$ & \\
\hline 11 & Poaceae & Eleusine indica (L.) Gaertn. ${ }^{2}$ & Rumput Belulang & * & $*$ & & * & \\
\hline 12 & Rubiaceae & Spermacoce confusa Rendle $^{2}$ & Kerekah Batu & & * & & * & \\
\hline 13 & $\begin{array}{l}\text { Fabaceae } \\
\text { (Mimosacaceae) }\end{array}$ & Leucaena leucochepala (Lam.) de $\mathrm{Wit}^{2}$ & Lamtoro & * & $*$ & & $*$ & \\
\hline
\end{tabular}




\section{CONCLUSION}

The three species of stingless bees found were new records in West Halmahera. The most common species being Tetragonula clypearis (Friese), followed by $T$. sapiens (Cockerell), and last T. biroi (Friese). Colonies were mostly found in parts of public houses $(80.39 \%)$, followed by plantations $(13.73 \%)$, and the community forest $(5.88 \%)$, respectively. Most colonies nested in stone cavities, parts of the homes, wooden materials, tree trunks, logs, tree roots, bamboo, and sometimes iron cavities. The dominant forage plants suitable for these bees were forage plantation, crops, fruits, vegetables, ornamental flowers, wild plants and shrubs.

\section{ACKNOWLEDGEMENT}

This research was supported by the SEAMEO BIOTROP PhD Thesis Grants Program to HS. We thank the academic community of Banau Agricultural School of Entrepreneurship for help in collecting bees; the Entomology Laboratory staff, LIPI-Cibinong, for assistance in the identification of species and morphological comparisons; and the Government of West Halmahera District who supported this research activity. The participation of MSE and his visit to Indonesia was supported by funds from the late C.D. Michener at the University of Kansas Natural History Museum.

\section{REFERENCES}

Backer CA, Brink VDRCBJ. 1963. Flora of Java (Spermatophytes Only). Volume I. Groningen, The Netherland: NVP Noordhoff.

Backer CA, Brink VDRCBJ. 1965. Flora of Java (Spermatophytes only). Volume II. Groningen, The Netherland: NVP Noordhoff.

Backer CA, Brink VDRCBJ. 1968. Flora of Java (Spermatophytes only). Volume III. Groningen, The Netherland: NVP Noordhoff.

Boontop Y, Malaipan S, Chareansom K, Wiwatwittaya D. 2008. Diversity of stingless bees (Apidae: Meliponini) in Thong Pha Phum District, Kanchanaburi Province, Thailand. Kasetsart J - Nat Sci. 42(3):444-456.

Chuttong B, Chanbang B, Burgett MD. 2015. Meliponiculture: Stingless bee beekeeping in Thailand. Bee World. 91(2):41-45.

Dollin AE, Dollin LJ, Sakagami SF. 1997. Australian stingless bees of the genus Trigona (Hymenoptera: Apidae). Invertebr Syst. 11(6):861-896.

Eltz T, Brühl CA, Imiyabir Z, Linsenmair KE. 2003. Nesting and nest trees of stingless bee (Apidae: Meliponini) in lowland dipterocarp forests in Sabah, Malaysia, with implication for forest management. For Ecol Manage.
172(2-3):301-313

Engel M., Kahono S, Peggie D. 2018. A key to the genera and subgenera of stingless bees in Indonesia (Hymenoptera: Apidae). Treubia. 45(December):6584.

Engel MS. 2019. Notes on Papuasian and Malesian stingless bees, with the description of new taxa (Hymenoptera: Apidae). J Melittology. 88:1-25.

Engel MS, Dingeman-Bakels F. 1980. Nectar and pollen resources for stingless bees (Meliponinae, Hymenoptera) in Surinam (South America). Apidologie. 11(4):341-350.

Engel MS, Michener CD, Boontop Y. 2017. Notes on Southeast Asian stingless bees of the genus Tetragonula (Hymenoptera: Apidae), with the description of a new species from Thailand. Am Museum Novit.(3886):1-20.

Engel MS, Rasmussen C. 2021. Corbiculate Bees. In: Encycl Soc Insects. Star, C.K. Cham, Switzerland: Springer; hal. 302-310.

Halcroft M, Spooner-Hart R, Dollin A. 2013. Australian Stingless Bees. In: Vit P, Pedro SR., Roubik D., editor. Pot Honey A Leg Stingless Bees. Berlin, Germany: Springer Verlag; hal. 37-72.

Jongjitvimol T, Wattanachaiyingcharoen W. 2007. Distribution, nesting sites and nest structures of the stingless bee species, Trigona collina Smith , 1857 ( Apidae , Meliponinae ) in Thailand. Nat Hist Chulalongkorn Univ. 7(1):25-34.

Kahono S, Chanatawannakul P, Engel MS. 2018. Social bees and the current status of beekeeping in Indonesia. In: Chantawannakul P, Williams G, Neumann P, editor. Asian Beekeep 21st century. Singapore: Springer Nature; hal. 287-306.

Kelly N, Farisya MSN, Kumara TK, Marcela P. 2014. Species diversity and external nest characteristics of stingless bees in meliponiculture. Pertanika J Trop Agric Sci. 37(3):293-298

Kumar M., Singh AJA., Alagumuthu G. 2012. Traditional beekeeping of stingless bee (Trigona $\mathrm{sp}$ ) by Kani tribes of Western Ghats, Tamil Nadu, India. Indian J Tradit Knowl. 11(2):342-345.

Michener CD. 2007. The Bees of the World. 2nd Ed. Baltimore: Johns Hopkins University Press.

Nayak P., Reddy S., Jayaprakash. 2013. Nesting pattern preferences of stingless bee, Trigona iridipennis Smith (Hymenoptera: Apidae ) in Jnanabharathi Campus , Karnataka , India. 2(2):44-50.

Putra D., Dahelmi, Salmah S., Swasti E. 2016. Species diversity of stingless bees (Hymenoptera: Meliponini) in chili pepper (Capsicum annum L.) plantation in West Sumatera. Int J Sci Res. 5(4):1527-1532.

Putra NS, Watiniasih NL, Suartini M. 2016. Jenis lebah trigona (Apidae: Meliponinae) pada ketinggian tempat berbeda di Bali. J Simbiosis. 4(1):6-9. 
Ramalho M, Kleinert-Giovannini A, Imperatriz-Fonseca V. 1990. Important bee plants for stingless bees (Melipona and Trigonini) and Africanized honeybees (Apis mellifera) in neotropical habitats: a review. Apidologie. 21(5):469-488.

Rasmussen C. 2008. Catalog of the IndoMalayan/Australasian stingless bees (Hymenoptera: Apidae: Meliponini). Zootaxa. 1935:1-80.

Rasmussen C. 2013. Stingless bees (Hymenoptera: Apidae: Meliponini) of the Indian subcontinent: Zootaxa. 3647(3):401-428.

Rasmussen C, Thomas JC, Engel MS. 2017. A new genus of Eastern Hemisphere stingless bees (Hymenoptera: Apidae), with a key to the supraspecific groups of Indomalayan and Australasian Meliponini. Am Museum Novit. 3888:1-33.

Rathor VS, Rasmussen C, Saini MS. 2013. New record of the stingless bee Tetragonula gressitti from India (Hymenoptera: Apidae: Meliponini). J Melittology. $7: 1-5$.

Roopa AN, Eswarappa G, Sajjanar SM, Gowda G. 2017. Study on identification of pasturage sources of stingless bee (Trigona iridipennis Smith.). Int J Curr Microbiol Appl Sci. 6(11):938-943.

Sakagami SF. 1978. Tetragonula stingless bees of the Continental Asia and Sri Lanka (Hymenoptera, Apidae). J Fac Sci Hokkaido Univ Zool. 21(2):165247.

Sakagami SF, Inoue T. 1985. Taxonomic notes on three bicolorous Tetragonula stingless bees in Southeast
Asia. Kontyû. 53(1):174-189.

Salim HMW, Dzulkiply AD, Harrison RD, Fletcher C, Kassim AR, Potts MD. 2012. Stingless bee (Hymenoptera: Apidae: Meliponini) diversity in dipterocarp forest reserves in Peninsular Malaysia. Raffles Bull Zool. 60(1):213-219.

Schwarz F. 1939. The Indo-Malayan Species of Trigona. Bull Am Museum Nat Hist. 76(3):83-141.

Sommeijer MJ. 1999. Beekeeping with stingless bees: A new type of hive. Bee World. 80(2):70-79.

Starr CK, Sakagami SF. 1987. An extraordinary concentration of stingless bee colonies in the Philippines, with notes on nest structure (Hymenoptera: Apidae: Trigona spp.). Insectes Soc. 34(2):96-107.

Suriawanto N, Atmowidi T, Kahono S. 2017. Nesting sites characteristics of stingless bees (Hymenoptera: Apidae) in Central Sulawesi, Indonesia. J Insect Biodivers. 5(10):1-9.

Syafrizal S, Bratawinata AA, Sila M, Mariji D. 2012. Jenis lebah kelulut (Trigona spp.) di Hutan Pendidikan Lempake. Mulawarman Sci. 11(1):11-18.

Syafrizal, Tarigan D, Yusuf R. 2014. Keragaman dan Habitat Lebah Trigona pada Hutan Sekunder Tropis Basah di Hutan Pendidikan Lempake, Samarinda, Kalimantan Timur. J Teknol Pertan. 9(1):34-38.

Widhiono I, Sudiana E, Trisucianto E, Darsono. 2016. Keragaman Serangga Penyerbuk di Lereng Gunung Slamet dan Sekitarnya. Purwokerto, Indonesia: Universitas Jenderal Soedirman. 